\title{
Is kerkvereniging vandag of in die toekoms 'n doelwit?
}

\author{
SJ Botha
}

\section{Abstract \\ The unification of the three Afrikaans Churches: \\ An obtainable goal?}

The purpose of this paper is to consider the question whether uniting or amalgamating the three Afrikaans Churches into one organisation is an obtainable goal at present or in the foreseeable future. In an attempt to achieve an answer to the question the following issues were taken into consideration:

1. The historical events of a century ago when an attempt was made to unite the churches.

2. The viewpoint which the Nederduitsch Hervormde Kerk took during the past century on this matter.

3. The relation and differences among the three churches in the past and at present.

\section{INLEIDEND}

Kerkvereniging is ' $n$ saak wat in Suid-Afrika sedert die ontstaan van drie kerke onder die Afrikanervolk dikwels opgehaal is en steeds opgehaal word. Ietsie meer as ' $n$ honderd jaar gelede is daar selfs 'n poging aangewend om twee van die drie kerke te vereniging, hoewel die poging feitlik totaal misluk het (Engelbrecht 1953: 281-352). Dit is veral in die laaste dekades dat daar met baie groot klem oor die saak gepraat word. Van tyd tot tyd is en word voorstelle tot kerkvereniging ook gemaak. So onlangs as 1980 het dr J C Kruger wat eers predikant in die Gereformeerde Kerke was, en later ook predikant in die Nederduitse Gereformeerde Kerk, met die voorstel van kerkvereniging tussen dié twee genoemde kerke gekom. Volgens hom het die Nederduitse Gereformeerde Kerk reformasie tot strenger tug en die Gereformeerde Kerke weer reformasie tot doeltreffender evangelisasie nodig, en die enigste

- Lesing gehou by die kongres van die Kerkhistoriese Genootskap van die Nederduitsch Hervormde Kerk op Vrydag 14 Februarie 1986. 
weg tot hierdie reformasie sou deur kerkvereniging tussen die twee kerke bereik kan word (Kruger 1980: 144).

Dit is egter ook baie duidelik dat die drie kerke totaal verskillend dink oor kerkvereniging of die organisatoriese eenwording van die kerke. Die Gereformeerde Kerke en die Nederduitse Gereformeerde Kerk se denke in dié verband lê die naaste aan mekaar. Die Gereformeerde Kerk het reeds in 1958 die standpunt ingeneem dat 'die eenheid van die uitwendige kerk ... 'n goddelike eis en opdrag' is en dat dit daarom roeping is om een kerkverband tot stand te bring (Notule TKK 1958: 86). Hierdie standpunt was heelwat anders as die vroeëre standpunt wat in 1913 in die Gereformeerde Kerke gegeld het. Toe is op die standpunt van die Nederduitsch Hervormde of Gereformeerde Kerk, dat die einddoel van samewerking tussen die kerke kerkvereniging moes wees, geantwoord 'dat die gedagte dat die Hollandssprekende bevolking maar één kerk mag hê, geen rekening hou met die loop van die geskiedenis in die ontstaan van die kerke nie, nòg van die amp van die gelowige in elke plaaslike gemeente om te waak vir die kenmerke van die ware kerk en dat daarom die samewerking van alle gelowiges in een kerklike liggaam nie deur kunsmatige samebinding tot stand moet kom nie' (Borchardt 1974: 191).

Vanuit die Nederduitse Gereformeerde Kerk is die gedagte van kerkvereniging gereeld gehoor. In onlangse dekades is veral deur Nederduitse Gereformeerde woordvoerders verwys na die 'sondige verskeurdheid van die drie Afrikaanssprekende susterskerke', om so blykbaar ' $n$ dwingende argument op te werp waarom die drie kerke organisatories een moet word (Pont [1977]: 1).

Hoewel die eenheid van die kerk tot dusver nog nie deur die twee kerke tot 'n verdere nota ecclesia verklaar is, soos al gebeur het vanuit die Wêreldraad van Kerke nie (Steenkamp 1982: 171), neig dit by baie van hulle woordvoerders reeds in die rigting.

Die Nederduitsch Hervormde Kerk het hierteenoor 'n totaal ander standpunt oor die organisatoriese eenwording of kerkvereniging ingeneem. Sedert die Kerk ' $n$ honderd jaar gelede deur 'n verkeerd-gemotiveerde en kunsmatig-bewerkte kerkvereniging ernstig geknou is, het die Kerk ' $n$ baie versigtige houding ten opsigte van kerkvereniging ingeneem. Die Kerk het ernstig oor die vraag besin of die feit van die bestaan van die drie kerke onder die Afrikaner op sigself noodwendig die eenheid van die kerk van Jesus Christus skaad en of die organisatoriese eenheid van die drie kerke 'n dwingende Bybelse eis is of nie. As resultaat van die besinning het die Kerk tot dusver nog altyd die 
standpunt ingeneem dat kerkvereniging of organisatoriese eenwording tussen die drie Afrikaanse kerke nie noodwendig is vir kerklike eenheid of die eenheid van die kerk van Jesus Christus onder die Afrikanervolk nie.

Om by geleentheid van die dankbare feestelikhede oor die voorreg en wonder van ' $n$ verdere honderd jaar van kerkwees die vraag na kerkvereniging te oorweeg, het sekerlik ten doel dat die Kerk hom weer sal vergewis van sy standpunt. Hoewel daar in die vraagstelling alleen van die hede en die toekoms sprake is, maak die konteks waarbinne hierdie vraag oorweeg moet word, naamlik as deel van die dankfees oor die afgelope honderd jaar van kerkwees, dit feitlik vanselfsprekend dat by die beantwoording van die vraag die geskiedenis van die afgelope honderd jaar sal meespreek.

\section{HOUDING VAN DIE NEDERDUITSCH HERVORMDE KERK EN DIE EERSTE JARE NA DIE POGING TOT KERKVERENIGING VAN 1885}

Die besluit van die Konsulentsgemeente van Pretoria op 13 Februarie 1886 te Witfontein, en herhaal op 20 Februarie 1886 te Rhenosterpoort, word as beginpunt in die verlede geneem (Engelbrecht 1953: 307):

'Maakt gene objectie omtrent het niet opnemen dezer Gemeente in de rij der Gemeenten van de Nederduitsch Hervormde of Gereformeerde Kerk. Gevoelt ons integendeel tevreden te blijven hetgeen wij was en nu nog ben, namelijk: Ned. Herv. Deze vergadering verklaart verder, dat zij onder geene omstandigheden zullen aansluiten bij die Kerkgenootschap, waardoor inbreuk zal kunnen worden gemaakt op de naam en regten van de Ned Herv Kerk, zooals dezelve zijn neergelegd in art. 20 onzer Grondwet.

Van deze kerk onzer vaderen willen wij geen afstand doen en verzoek onze Eerwaarde Kerkeraad iedere geoorloofde middel in het werk te stellen en hunne uiterste best te doen, opdat dit kostbaar kleinood voor ons en onze kinderen bewaard moge blijven, belovende krachtig te zullen medewerken in alles dat onze pligt van ons vordert ter behoud van dit heerlijk doel.

Alle leden van de Ned Herv Kerk in de Z.A. Republiek worde door ons als zoodanige met broederlijke liefde erkend en ontvangen.'

Met hierdie besluit het die Konsulentsgemeente van Pretoria in die eerste plek die beslissing van die eerste Algemene Kerkvergadering 
van die nuwe verenigde kerk, wat onder die naam Nederduitsch Hervormde of Gereformeerde Kerk vanaf 7 Desember 1885 te Pretoria vergader het, aanvaar. Dit het hulle gedoen ondanks die feit dat die genoemde beslissing van die Algemene Kerkvergadering van die Ned Herv of Geref Kerk self ultra vires was (Pont [1977]: 36). Tweedens is met die besluit van die Konsulentsgemeente verseker dat nie alleen dié gemeente nie, maar ook talle ander lidmate en ampsdraers van oor die hele Zuid-Afrikaansche Republiek wat die historiese Nederduitsch Hervormde Kerk graag wou handhaaf, kon bly wat hulle nog altyd was, naamlik Nederduitsch Hervormd. Op dié wyse is verseker dat die Nederduitsch Hervormde Kerk sonder 'n breuk in die historiese en kerkregtelike lyn, gehandhaaf is. Hierteenoor was die verenigde kerk'n heeltemal nuwe kerk wat tot stand gekom het deurdat die Nederduitsch Gereformeerde Kerk opgehef is om saam met ' $n$ deel van die lidmate van die Nederduitsch Hervormde Kerk wat daartoe bereid was die verenigde kerk tot stand te bring.

Die besluit van die Konsulentsgemeente het verder baie duidelik aan die lig laat kom dat ' $n$ baie groot getal van die lidmate en ook baie ampsdraers van die Nederduitsch Hervormde Kerk nooit verenig het nie omdat hulle nie wou verenig nie. Hierdie lidmate en ampsdraers het hulle daarom ook van oral oor die Zuid-Afrikaansche Republiek by die Konsulentsgemeente geskaar en die besluit ten volle onderskryf. Na raming was dit goed die helfte van die lidmate wat nooit verenig het nie, terwyl baie ander lidmate en ampsdraers wat wel verenig het, om verskeie redes spoedig na die Nederduitsch Hervormde Kerk begin terugkeer het. Die gevolg was dat die kerkvereniging van 1885 nie alleen feitlik heeltemal misluk het nie, maar dat groter twis, stryd en verwarring op die Transvaalse kerkerf as ooit tevore ontstaan het.

Uiteindelik spreek dit seker feitlik vanself dat waar hierdie besluit van 'n honderd jaar gelede ook die resultaat was van 'n grootliks ongewenste en onbekookte kerkvereniging, die saak van kerkvereniging deur hulle wat hierdie besluit moes neem, voortaan heeltemal anders benader sou word. Die Kerk het geleer dat al mag dit ook so wees dat die strewe tot groter kerklike eenheid deur kerkvereniging na 'n hoë en eerbare ideaal lyk, bly dit steeds 'n baie delikate aangeleentheid wat met die grootste omsigtigheid benader moet word. By die kerkvereniging van 1885 is daar hoegenaamd nie hiermee rekening gehou nie, met tragiese gevolge vir kerklike eenheid. Daar bestaan vyf redes waarom die vereniging misluk het:

- In die eerste plek het die grondmotief vir die kerkvereniging nie op 
die Bybels-kerklike nie, maar op die nasionaal-politieke terrein ontspring. Die drang tot kerkvereniging het naamlik sy oorsprong gehad in die eenheidstrewe en samehorigheidsgevoel wat onder Afrikaners wakker gemaak is deur die belewing van die anneksasie van die Zuid-Afrikaansche Republiek deur Engeland in 1877 en die daaropvolgende suksesvolle Eerste Vryheidsoorlog van 1880-1881 (Duvenhage 1985: 48 en Botha 1985: 8). In die hele saak is daar nooit werklik na die wil van God gevra nie.

- Tweedens was die gesindhede en verskille tussen die twee deelnemende kerke van so ' $n$ aard dat dit 'n suksesvolle kerkvereniging vanuit die staanspoor, indien nie onmoontlik nie, dan minstens uiters onwaarskynlik gemaak het (Botha 1985: 9).

- Derdens is op ' $n$ uiters argelose en oppervlakkige wyse oor die saak van kerkvereniging onderhandel. Nòg die twee kommissies wat namens die kerke met mekaar oor die grondslae van 'n vereniging onderhandel het, nòg die twee Algemene Kerkvergaderings wat die finale besluite moes neem, het ooit tot werklike teologiese diepgang in hulle diskussies gekom. Van die noodsaaklike voorafgaande diepte-studie oor die tersaaklike teologiese en kerkregtelike aangeleenthede was daar hoegenaamd geen sprake nie. Vir enige verskille is die oë en ore eenvoudig gesluit.

- In die vierde plek is daar nie na die tydige en goed bedoelde vermaning, nog voor daar met onderhandelinge begin is, van die kant van 'n leiersfiguur soos Paul Kruger geluister nie:

'Nu is er plan om de drie kerken te vereenigen; maar als ik daarover spreekt dan beef ik bijkans. Bij die poging tot vereeniging moet geen dwang wezen, want dan worden wij paus en treden in de plaats van Jezus.'

Gemeentelede het nooit 'n kans gekry om hulle oor die saak uit te spreek nie en toe wel by wyse van memories geprotesteer is, is dit eenvoudig as òf te vroeg of te laat en dus buite orde gereël (Engelbrecht 1953: 297-298). Uiteindelik is hulle voor 'n voldonge feit gestel dat die Algemene Kerkvergaderings hulle in ' $n$ kerkvereniging wou indwing.

- In die vyfde plek is 'n baie sterk saak uit te maak dat die kerkvereniging van 1885 in der waarheid 'n poging was van die Nederduitsch Gereformeerde predikante, $\mathrm{HL}$ en $\mathrm{HJ}$ Neethling, om met behulp van die voormalige Stellenbosse proponente binne die Nederduitsch Hervormde Kerk, die Hervormde Kerk oor te neem. In die poging is die nasionaal-politieke eenheidsgevoel baie handig 
gebruik. Uit die Konsulentsgemeente van Pretoria was dit ouderlinge Christiaan Joubert en Vaal Martiens Prinsloo wat uiteindelik besef het dat die kerkvereniging 'n uitoorlê-aksie was (Pont 1986: 9-10).

Al het die kerkvereniging van 1885 feitlik misluk, het dit die Nederduitsch Hervormde Kerk tog ernstig geknou. Dit was 'n gedisorganiseerde kerk, sonder 'n enkele predikant en byna al sy eiendomme kwyt. Die oë moes na Holland gerig word vir 'n predikant en teësinnig moes die Kerk hom op die hooggeregshof beroep om van sy eiendomme terug te kry (Botha [1961]: 1). Hierdie ondervinding rondom kerkvereniging moes eenvoudig ' $n$ negatiewe houding ten opsigte van die saak van kerkvereniging by die Nederduitsch Hervormde Kerk tot gevolg hê. By 'n soortgelyke kerkvereniging sou die Nederduitsch Hervormde Kerk nie meer betrokke wou raak nie.

Tog het dit nie vir die Nederduitsch Hervormde Kerk ingehou dat hy die houding moes inneem dat die eenheid van die kerk van Jesus Christus nie ' $n$ belangrike saak was nie. Hierdie eenheid moet egter nie primêr gesoek word in die eenheid van organisasie nie, maar in eenheid van geloof.

Dat hierdie eenheid vir die Kerk 'n saak van groot erns was, het gou duidelik geword toe reeds op die eerste Algemene Kerkvergadering na die kerkvereniging, wat vanaf 13 Februarie 1888 in Pretoria gesit het, aan die verhouding tot ander kerke aandag gegee is. Die atmosfeer was wel gespanne en emosiebelaaid en dit kon maklik tot 'n ongenaakbare en veglustige standpunt gelei het. Die Algemene Kerkvergadering het egter, ook mede vanweë die leiding van ds MJ Goddefroy, 'n baie ewewigtige houding ingeneem. Aan die een kant moes die goeie reg van bestaan van die Nederduitsch Hervormde Kerk onwrikbaar gehandhaaf bly, maar terselfdertyd is die broederhand na die ander kerke, ook na die Nederduitsch Hervormde of Gereformeerde Kerk, uitgesteek en die eenheid in geloof erken (Botha 1981: 77). Goddefroy het dit soos volg opgesom:

'Wij staan als leden van de Ned. Herv. Kerk op den bodem van Gods Woord, ons houdende aan de leer onzer oude Ned. Herv. Kerk, maar warsch van alle priesterheerschappij.

Daarom is ons, hoewel wij naar eenheid streven, de eenheid dié ons van andere zijde werd aangeboden te duur! Wij willen geen eenheid voor het uitwendige, ten koste onzer vrijheid; maar inwendige eenheid, zooals die uitgesproken is in het $17 \mathrm{e}$ hoofdstuk 
van het Evangelie van Johannes, zij is een band, uitnemender dan alle menschelijke verbanden, en die het meest kenbaar wordt in nood en gevaar.'

In die Herderlike Skrywe wat van dieselfde Algemene Kerkvergadering uitgegaan het, is dié houding ook onderstreep (Botha 1981: 77).

'Wij zijn en blijven leden der Nederduitsch Hervormde Kerk! Wij kunnen niet anders; het is de Kerk onzer vaderen, gewaarborgd bij de Grondwet, gesteunt door den Volksraad. Wij willen niemand dwingen, maar kunnen ons ook geen dwang laten welgevallen.'

'Wij zijn warsch van twisten. Beter is eenigheid des geloofs en der liefde tusschen twee naast elkander staande kerken, wedijverende in het heerlijk streven door Paulus aangewezen (Eph. 4:15) een wedstrijd voor waarheid en vrede!'

Hierdie standpunt wat so kort na die ondervinding in verband met 'n kerkvereniging deur die Algemene Kerkvergadering van 1888 ingeneem is, was vir die Nederduitsch Hervormde Kerk nie net in die eerste jare van die afgelope honderd jaar rigtinggewend nie, maar het in beginsel tot vandag die basiese standpunt van die Kerk gebly.

$\mathrm{Al}$ is dit so dat die Kerk nog altyd onwrikbaar sy goeie reg van bestaan gehandhaaf en erken wou sien, was daar terselfdertyd nog altyd ' $n$ gesindheid van erkenning, respek en agting vir die ander twee Afrikaanse kerke. Trouens dit was die gesindheid teenoor elke kerk wat as ware kerk deur die Nederduitsch Hervormde Kerk erken is en dit is nog altyd deur die Nederduitsch Hervormde Kerk aanvaar en erken dat die ander twee Afrikaanse kerke ware kerke is (Botha 1981: 79). Implisiet lê daarin ook opgesluit die verbandhoudende standpunt van die Nederduitsch Hervormde Kerk dat terwyl hy daaraan vashou dat hy ooreenkomstig sy belydenis openbaring van die een heilige, algemene Christelike kerk is, hy tog nie die enigste ware kerk onder die Afrikaner is nie (Kerkwet van die Nederduitsch Hervormde Kerk 1983 Artikel 1).

As die geskiedenis van die afgelope eeu nou in dié verband verder nagegaan word, blyk hierdie standpunt en gesindheid van die Nederduitsch Hervormde Kerk baie duidelik. Terloops kan daarop gewys word dat ds Goddefroy, aan die begin van die afgelope eeu, rigtinggewende leiding gegee het dat hierdie standpunt, houding en gesindheid in die Nederduitsch Hervormde Kerk ingeneem is (Botha 1981: 79). 
Vanuit hierdie standpunt en gesindheid was dit vanselfsprekend in die Nederduitsch Hervormde Kerk dat die ander twee kerke genooi sou word om deur middel van verteenwoordigers minstens die opening van die Algemene Kerkvergaderings by te woon. Daarmee is volhard selfs al het die Nederduitsch Hervormde of Gereformeerde Kerk hierdie uitnodigings aanvanklik van die hand gewys (Borchardt 1974: 182 en Botha 1981: 78). Ook die versoek tot kanselruil aan die ander twee kerke reeds so vroeg as in 1894 was 'n logiese uitvloeisel van die genoemde standpunt (Borchardt 1974: 183). Terwyl die Gereformeerde Kerke steeds kanselruil afwys, het die Nederduitse Gereformeerde Kerk tog mettertyd hieraan gehoor gegee en kan en het dit wel gebeur dat by geleentheid kanselruil plaasgevind het.

\section{DIE JARE 1900 TOT 1938}

Hoewel die Tweede Vryheidsoorlog 1899-1902 enige gesprekke of toenaderingspogings tussen die drie kerke voorlopig tot 'n einde gebring het, was die Nederduitsch Hervormde Kerk weer die eerste om na die oorlog besluite ten opsigte van toenadering te neem. By die Algemene Kerkvergadering van Junie 1903 het ouderling ADW Wolmarans 'n beskrywingspunt ingedien: 'dat wederom onzerzijds pogingen aangewend worden om tot eene toenadering of nauwere broederband te komen' met die Gereformeerde en die Nederduitsch Hervormde of Gereformeerde Kerke. Die saak is na 'n kommissie 'voor nauwere vereeniging' verwys wat aanbeveel het dat die beskrywingspunt aanvaar moes word (Borchardt 1974: 186). In sy skrywe aan die twee ander kerke het die skriba van die Algemene Kerkvergadering, ds J van Belkum, ook die terme 'nauwere vereeniging der Hollandsche Kerken' gebruik.

Dit het ongelukkig verkeerde verwagtings en verwarring by die ander twee kerke geskep (Borchardt 19.74: 187-188). Nòg Wolmarans nòg die Nederduitsch Hervormde Kerk het ander 'eene toenadering of nauwere broederband' iets soos organisatoriese eenwording op die oog gehad. Ongelukkig is ook nie nader uitgespel wat met hierdie uitdrukking bedoel is nie. Waarskynlik is daaronder verstaan die wedersydse erkenning van mekaar as kerke, gesprek met mekaar oor gemeenskaplike sake en kanselruil. Met ander woorde nie iets anders as die standpunt en houding wat reeds tevore gegeld het nie. In elk geval het dit op die lang duur tot geen noemenswaardige resultate gelei nie.

In die jare tot 1928 het stadigaan 'n meer 'ontspanne' verhouding 
tussen die drie kerke begin posvat. Groeteboodskappe is op mekaar se Algemene Kerkvergaderings oorgedra en hulle het mekaar ook dikwels geken 'in sake gesamentlike optrede ten opsigte van biddae, sosiale vraagstukke en ook die vertaling van die Bybel in Afrikaans' (Borchardt 1974: 191).

In 1928 het die Nederduitsch Hervormde of Gereformeerde Kerk aan die Nederduitsch Hervormde Kerk die versoek gerig om deur middel van kommissies van sewe lede elk met mekaar te onderhandel oor sake soos die erkennig van mekaar se lidmaatskap, die toelating van 'n ander kerk se dooplidmate tot belydenis van geloof, en so meer. By die twee byeenkomste wat op 28 Augustus 1928 en 12 Junie 1930 plaasgevind het, het ' $n$ lang memorandum van die kommissie van die Ned Herv of Geref Kerk as basis van bespreking gedien. Sake soos die erkenning van mekaar se reg van bestaan, erkenning van mekaar se tug, ensovoorts moes bespreek word. Die Nederduitsch Hervormde Kerk se kommissie wou weet of die Hervormde Kerk erken word as die Hervormde Kerk wat in 1853 sy eerste Algemene Kerkvergadering gehou het. Daar is toe wel besluit dat die kommissies hulle onderskeie kerke sou versoek om hulle oor die verhouding tussen die twee kerke uit te spreek (Borchardt 1974: 192-195).

By 'n vergadering van die twee kommissies op 10 Desember 1931 het die kommissie van die Ned Herv of Geref Kerk rapport gedoen dat hulle vergeet het om die kwessie van erkenning van die Hervormde Kerk voor die Sinode te lê (Borchardt 1974: 193). Hierna wou sake nie verder vlot nie en is ook geen verdere vergaderings gehou nie. Uiteindelik het die kommissie van die Hervormde Kerk in 1937 versoek om ontbind te word.

\section{DIE INTERKERKLIKE KOMMISSIE}

Intussen het daar 'n ander ontwikkeling plaasgevind wat uitgeloop het op die totstandkoming van die Interkerklike Kommissie wat later by herstrukturering, die steeds bestaande Tussenkerklike Kommissie sou word. Die inisieerder van hierdie nuwe ontwikkeling was ds LE Brandt. As voorsitter van die Algemene Kerkvergadering van die Nederduitsch Hervormde Kerk het hy in Maart 1933 die Raad van gefedereerde Ned Geref Kerke toegespreek en gevra of dit nie moontlik sou wees om ' $n$ interkerklike kommissie op te rig nie, want volgens hom kon 'nadere kennismaking en samewerking ... die belange van die volk en die saak van die Here dien en bevorder' (Grobler 1983: 235). 
In 1934 het hy die saak verder gevoer op die Sinode van die Ned Herv of Geref Kerk en in ' $n$ brief aan die Gereformeerde Kerk.

Die Interkerklike Kommissie het na 'n paar jaar wel tot stand gekom, maar by die eerste vergadering van 14 Mei 1939 het geen verteenwoordigers van die Nederduitsch Hervormde Kerk sitting geneem nie. Dit sou nog tot 1942 duur voordat die Hervormde Kerk se verteenwoordigers sitting sou neem. Verskeie redes kan vir hierdie 'vertraagde' deelname aangevoer word, naamlik hernude spanning met die Ned Geref en die Ned Herv of Geref Kerke, die feit dat die ander twee kerke nog steeds nie besluite van die vorige eeu dat die Hervormde Kerk 'n valse kerk is herroep het nie en die Hervormde Kerk formeel as susterkerk erken het nie, en verder ook verskille wat in die Hervormde Kerk self bestaan het oor samewerking in so 'n interkerklike kommissie (Borchardt 1974: 198-199 en Grobler 1983: 242-243).

Die spanning het mettertyd verminder en hoewel die ander twee kerke nie die besluite oor die Hervormde Kerk as 'n valse kerk wou herroep nie, het hulle darem verklaar dat hulle die Hervormde Kerk as susterkerk erken (Grobler 1983: 243).

In die Nederduitsch Hervormde Kerk self het daar oor ' $n$ moontlike kerkvereniging nie enige verskil van mening bestaan nie. In 1938 het die Kommissie van die Algemene Kerkvergadering die kerk se standpunt soos volg verwoord:

‘... dat die Hervormde Kerk nie ten gunste van 'n uitwendige, formele, organisatoriese vereniging is nie, maar dat die diepere eenheid alleen in die suiwere verkondiging van die Evangelie van Jesus Christus lê' (Borchardt 1974: 197).

Daar was egter wel stemme wat teen die Interkerklike Kommissie opgegaan het (Borchardt 1974:"199). Nogtans het die Hervormde Kerk wel besluit om deel te neem aan die Interkerklike Kommissie en vanaf 31 Maart 1942 is die vergaderings gereeld deur verteenwoordigers van die Hervormde Kerk bygewoon.

Dit moet egter goed in gedagte gehou word dat voordat sy verteenwoordigers sitting geneem het in die Interkerklike Kommissie die Hervormde Kerk homself uitdruklik oor kerkvereniging uitgespreek het. Voor die Algemene Vergadering van 20 Maart 1942 en volgende dae, het ' $n$ beskrywingspunt van die Gemeente Benoni gedien:

'Die H E Algemene Vergadering spreek die standpunt van ons kerk uit insake kerkvereniging tot voorligting van ons gemeente- 
lede' (Agenda van die Algemene Kerkvergadering 1942: Beskrywingspunt 28).

$\mathrm{Na}$ aanleiding van hierdie beskywingspunt is verklaar:

- 'Die Hoogeerwaarde Algemene Kerkvergadering betreur die verskeurdheid van die liggaam van Christus en begeer die eenheid daarvan, maar beskou dit so dat kerklike eenheid nie noodwendig in uiterlike organisasie gesoek hoef te word nie, maar wesenlik gevind moet word in 'n hoër geestelike eenheid in Christus, soos duidelik voorgelig deur die Skrif: ". . sodat hulle een kan wees" Joh. 17: 11; vgl. Ef. 4: 5, 6. Die verskeidenheid van kerke hoef nie juis die eenheid uit te sluit nie.'

- 'In hierdie gees verkies ons kerk die bestaande verskeidenheid van kerke met die onderlinge broederband, bo 'n oppervlakkige eenwording, indien dit sou meebring dat die prysgawe en verkragting van die beginsels en karakter van die Ned. Herv. Kerk soos gegrond op die Woord van God.'

- 'Die Hoogeerwaarde Kerkvergadering is van gevoel dat ons as Nederduitsch Hervormde Kerk deur kerkvereniging nie in ' $n$ NeoCalvinistiese of Metodistiese geestesrigting wil geraak nie. Sowel die leerheiligheid as die werkheiligheid is vreemd aan die gees en karakter van die Nederduitsch Hervormde Kerk. Die Nederduitsch Hervormde Kerk wil geen belydenis-kerk wees nie, maar belydende kerk.'

- 'Die enigste basis waarop kerkvereniging moontlik oorweeg kan word is op die histories-tradisioneel geworde grondslae en geestesrigting van ons vaders, soos beliggaam in ons Nederduitsch Hervormde Kerk' (Notule Algemene Kerkvergadering 1942: 31 en Rapport 21).

Die Hervormde Kerk het dus nie aan die Interkerklike Kommissie se werksaamhede deelgeneem met 'n organisatoriese eenwording tussen die drie Afrikaanse kerke as doelwit nie. Tog het die Hervormde Kerk wel tot die Interkerklike Kommissie toegetree en direk na sy toetrede het die Kommissie gepoog om 'n duideliker grondslag daar te stel. Die Kommissie het homself gesien as ' $n$ 'Verbond van Kerke' tussen die drie Afrikaanse kerke met die volgende grondslae:

- 'Elke kerk buig onvoorwaardelik voor die Woord van God - soos nader verklaar in ons drie Formuliere van Enigheid - en moet bereid wees om dienooreenkomstig te reformeer, waar nodig.' 
- 'Elke groep behou eie identiteit en selfstandigheid en verantwoordelikheid.'

- 'Die sondige toestand van kerklike gedeeldheid in die boesem van ons boerevolk moet gevoel, bely en bestry word, sodat die breuk in die waarheid en liefde geheel kan word.'

- 'Dit moet die kerkgroepe se besondere toeleg wees om met God se genade op Calvinistiese grondslag 'n onderlinge atmosfeer van liefde en vertroue te skep waardeur:

- ' $n$ beter gesindheid jeens mekaar as lede van die liggaam van Christus sal ontstaan;

- 'n vrugbare tugoefening of dissipline moontlik sal wees; die een kerkgroep vir die ander tot oë en voete sal wees en

- hulle met graagte na mekaar se voorligting of vermanings sal wil luister en mekaar se goeie voorbeeld sal wil navolg;

- die weg inderdaad voorberei sal word vir 'n al nouer kerklike samelewing en samewerking' (Grobler 1983: 246).

Hoewel hierdie grondslae nooit nader uitgespel is nie en hoewel daar heelwat vrae oor hierdie grondslae gevra kan word, is dit in elk geval duidelik dat kerkvereniging nie as ' $n$ doelwit in die grondslae ingebou was nie. Implisiet is die afsonderlike bestaan van die drie Afrikaanse kerke nie noodwendig as in beginsel verkeerd en 'n sondige verskeurdheid beoordeel nie. Daarmee kon die Nederduitsch Hervormde Kerk akkoord gaan en sy samewerking dus gee.

In die volgende jare is deur die Interkerklike Kommissie aan 'n groot aantal sake aandag gegee soos onder andere eerbiediging van mekaar se tug, weerstand teen Roomse invloede en gevare, die Gereformeerde Ekumeniese Beweging, hersiening van die Psalmboek, onderwyssake, kultuursake, volksverdeeldheid, en so meer. Interessant is ook dat in 1947 ondersoek gedoen is na 'n skema vir 'volkome ekonomiese, maatskaplike en geografiese segregasie wat deur die Kerke as beleid aanvaar kan word en by die owerheid bepleit kan word' (Grobler 1983: 243-245).

\section{DIE TUSSENKERKLIKE KOMMISSIE VAN DIE DRIE AFRIKAANSE KERKE}

Om verskeie redes (Borchardt 1974: 200-201 en Grobler 1983: 248-251) is egter op 6 Augustus 1958 'n herstrukturering van die Interkerklike Kommissie gemaak en het dit ook amptelik 'n nuwe naam, naamlik die 
Tussenkerklike Kommissie van die drie Afrikaanse kerke (TKK) gekry (Notule TKK 1958: 11).

As basis vir toekomstige samewerking is ' $n$ riglyn, deur die Gereformeerde Kerke voorgelê, aanvaar.

Ten opsigte van die wyse van benadering is besluit:

'Die veelheid van kerke word aanvaar, maar nie om daarby te berus nie. Dit was die standpunt van Calvyn, wat onverswak vasgehou het aan die Ecclesia universalis institutis. Hieruit is die gedagte van 'n Ekumeniese konvent gebore, bekend uit die korrespondensie met Cranmer (1556). Nie om die verskille te oorkoepel of 'n eenheidskultus op te rig oor die kerke heen nie, maar om die eenheid te soek en te vind. Die pluraliteit is nie maar 'n verskeidenheid nie, maar 'n sondige geskeidenheid wat nie mag wees nie. Die verskillende kerke moet nie gesien word as verskillende dele van een geheel nie, maar as stukke van ' $n$ geskeurde geheel (vgl. Inset. iv, 1, 2). Nie dat die liggaam van Christus geskeur is nie. Die eenheid van die kerk as mistieke liggaam van Christus is ' $n$ werklikheid, maar die eenheid van die uitwendige kerk is 'n goddelike eis en opdrag. Hieruit vloei die roeping van die kerk voort om dit wat uitmekaar hou, broederlik met mekaar onder oë te sien om sodoende te bring in een kerkverband' (Notule TKK 1958: $10)$.

Die metode van benadering sou wees:

- Die opstelling van memoranda, waarin wedersyds duidelik die punte neergelê sal word waarom die samesprekings gevoer moet word en dat die deputaatskappe na studie daarvan saamkom vir bespreking.

- Dat van hierdie samesprekinge van Sinode tot Sinode verslag gegee sal word vir vaslegging in die Acta ... (Notule TKK 1958: 10).

Dat in die wyse van benadering die ideaal van een kerkverband daargestel is, beteken ongetwyfeld dat hier ' $n$ besluit geneem is ten gunste van organisatoriese eenwording of kerkvereniging (Grobler 1983: 251). Dit is nogal merkwaardig dat die verteenwoordigers van die Hervormde Kerk blykbaar ook daarmee ingestem het, want op daardie stadium was daar in die Hervormde Kerk geen verandering van standpunt oor die saak van kerkvereniging nie.

Wat wel waar is, is dat op daardie stadium ook 'n baie sterk 'ekumeniese gees' in Suid-Afrika vaardig was. Veral by die Gereformeerde en Ned Geref Kerke het die gevoel van groter eenheid baie sterk bestaan omdat die Gereformeerde Ekumeniese Sinode in 1958 in Potchefstroom 
sou vergader en die Raad van die Nederduitse Gereformeerde Kerke dit ook as sy taak gesien het om 'n Suid-Afrikaanse Raad van Christelike Kerke tot stand te bring (Grobler 1983: 249-250).

In die klimaat en gedagtig daaraan dat die gesprek tussen die kerke oor dit wat hulle uitmekaar hou in elk geval realisme sou bring oor so 'n saak soos kerkvereniging, het die verteenwoordigers van die Hervormde Kerk geen besware geopper nie. Wat die metode van benadering betref was die Hervormde Kerk nog altyd ten gunste van samesprekings tussen die Afrikaanse kerke, veral ook oor sake waaroor daar verskille bestaan het. By 'n latere geleentheid sou dit ook duidelik blyk dat die Hervormde Kerk nie oor kerkvereniging van standpunt verander het nie.

Ten spyte van die nuwe struktuur en idealistiese basis van gesprek het die TKK vanaf sy vorming in 1958 vir byna sewe jaar nie een keer vergader nie. Die rede hiervoor was hernude spanning tussen die drie kerke oor verskeie aangeleenthede. Tussen die Ned Geref Kerke en die Gereformeerde Kerke oor sake rondom laasgenoemde se Eeufeesviering in 1959 en tussen die Ned Geref Kerke en die Hervormde Kerk oor sake rondom die interpretasie van die Suid-Afrikaanse Kerkgeskiedenis en veral rondom die sogenaamde Cottesloe-beraad (Grobler 1983: 251-254).

Toe die TKK weer vir die eerste keer op 14 April 1965 vergader het, het sommige verteenwoordigers met groot entoesiasme aanvaar dat 'daar blykbaar ' $n$ ernstige begeerte by al die lede bestaan om die drie Afrikaanse Kerke nader aan mekaar te bring met die oog op ewentuele eenheid' (Notule TKK 1965: 16). By ' $n$ volgende vergadering het ds PM Smith van die Hervormde Kerk ' $n$ korreksie hierop aangebring dat die woorde 'met die oog op ewentuele eenheid vir sy Kerk nie beteken dat die TKK hom doelbewus sal beywer vir organisatoriese kerkvereniging nie' (Notule TKK 1968: 24). Die Hervormde Kerk se standpunt het dus onveranderd gebly.

Die metode van benadering het beslis ' $n$ verbetering gebring in die funksionering van die TKK. Groter diepgang kan op die TKK self bereik word en ook by die gesprekke tussen die kerke afsonderlik. Die voorlegging van memoranda het aan die kerke die geleentheid gegee om hulle onderskeie standpunte deeglik te oorweeg en te verwoord en terselfdertyd noukeuriger kennis te neem van die ander een se standpunt.

Van die eerste memorandum wat op die wyse uitgereik is, het gehandel oor die kerkbegrip en oor ekumenisiteit (Notule TKK 1968: 
25-26). Van besondere betekenis oor die standpunt van die Hervormde Kerk met betrekking tot die eenheid van die kerk was 'n memorandum wat op 29 April 1969 voor die vergadering van die TKK gedien het. Die memorandum getitel, 'Kerk en Ekumene', is opgestel deur prof BJ Engelbrecht en is reeds in 1967 deur die Algemene Kerkvergadering goedgekeur (Notule TKK 1969: 79-89). Volgens die memorandum kan die enigste werklike grond vir die ekumeniese strewe die Bybelse leer van die eenheid van die kerk wees. Sulke motiewe soos die missionêre, die leerstellige en institutêre kan slegs sekondêre en aanleidende motiewe wees. Daar kan net een werklike eenheid van die kerk van Jesus Christus wees en dit is eenheid in Jesus Christus of dan eenheid in die waarheid. Numerieke eenheid sonder eenheid in die waarheid en geloof is leeg en sonder enige betekenis.

Die Hervormde Kerk bely op grond van die Heilige Skrif die eenheid en enigheid van die kerk van Jesus Christus (Notule TKK 1969: 80-81). In die Nederlandse Geloofsbelydenis en die Heidelbergse Kategismus word bely dat daar maar één kerk van Jesus Christus is en hierdie kerk is één in die eenheid van die geloof (Notule TKK 1969: 82).

Die Reformatore Luther, Calvyn en andere het in hulle teologie uitgegaan van die belydenis dat daar maar één kerk is en dat die kerk één is. Die kerk is egter geloofswerklikheid en daarom is dit nie moontlik of noodsaaklik dat die kerk as kerk en dus as eenheid vir algemene waarneming sigbaar verskyn nie. Die eenheid van die kerk bestaan in die geloof. Vir die ongelowige (= die wêreld) is die eenheid van die kerk onsigbaar, maar vir hom wat met erns kan sê credo unam sactam ecclesia is die kerk één.

Die Reformatore het egter geëis dat elkeen hom by die ware kerk moes voeg. Dit beteken dat die kerk tog ook sigbaar moet wees en hoe sal iemand nou weet of dit 'n ware kerk is of nie? Die antwoord is dat God sekere notae of symbola aan die ware kerk gegee het. Hierdie notae is die regte prediking en geloof, die regte sakramentsbediening en die regte Christelike lewe in liefde. Maar wat baie belangrik is: ook hierdie notae kan net deur die geloof geken word.

Samevattend gestel, lê die eenheid van die ecclesia universalis vir die reformatoriese belydenis en teologie in die eenheid van ware prediking, leer en geloof en die eenheid van regte sakramentsbediening. In die verband kom daar nou die belangrike vraag na vore wat die minimum basis van leer en geloof sou wees waarop die één kerk van Jesus Christus gebou kon word? In die saak het Calvyn se siening in twee uiteengeval: '(a) Binne die plaaslike gemeente en binne die Calvinis- 
tiese Kerkgenootskap as geheel wil hy 'n strenge eenheid van leer en sakramentsbediening handhaaf. (b) Maar wat die ander Kerkgenootskappe betref laat hy 'n groot verskeidenheid en vryheid toe. Hy erken dat daar ecclesiae contraversa bestaan, maar daar is tog soveel dinge gemeenskaplik wat nie die fidei unitatem dirimant nie' (Notule TKK 1969: 87).

Solank kerkgenootskappe dit in die capita doctrinae eens is, dan is hulle die één kerk en dan is die kerk één.

Luther het sy antwoord gesoek daarin dat hy in plaas van die woord 'kerk' eerder wou praat van die 'Christelike, heilige volk van God is één en bestaan uit verskillende gemeenskappe' (Notule TKK 1969: 87).

Hieruit volg dit dat kerke met dieselfde belydenis vir mekaar die één, heilige, algemene, Christelike kerk vorm. Kerke met verskillende belydenis (Calviniste en Lutherane) mag vind dat daar tussen hulle controversa bestaan. As hulle egter wat die capita doctrinae betref saamstem, moet hulle mekaar as lede van die een, heilige, algemene Christelike kerk erken. 'Wesenlik is hulle één kerk en deel van die één kerk; hulle is alleen verskillende gemeenskappe.'

Juis deur die metode van uitruil van memoranda het die punte van ooreenkoms, maar veral ook die sake waaroor daar verskille en dan soms diepgaande verskille bestaan het, aan die lig gekom. Dit het reeds gebeur by die memoranda oor ekumenisiteit dat die verskille in siening oor die eenheid van die kerk na vore gekom het. Die Nederduitsch Hervormde Kerk het onomwonde gestel dat hulle saam met die Reformatoriese leer en belydenis op grond van die Skrif daaraan vashou, dat daar slegs een eenheid van die kerk van Jesus Christus is en dit is die eenheid in die waarheid, afgesien van die organisasie in verskillende gemeentes en kerkverbande (Notule TKK 1970: 116-117). Hiermee stem die Ned Gefef Kerk in beginsel saam. Die verskil tree egter na vore as die toepassing op die drie Afrikaanse kerke gemaak word. Die Ned Geref Kerk aanvaar dat natuurlike verskille tussen verskillende volke in verskillende lande of selfs in dieselfde land nie één gemeenteverband en één kerkverband noodsaak nie. Waar dit egter by verskillende kerkverbande in een volk kom, verval die natuurlike verskille en word dit nou sondige verskeurdheid. Die Hervormde Kerk se standpunt is hierteenoor dat in lyn met die Reformatoriese visie oor die eenheid van die kerk dat waar as gevolg van historiese gebeure verskillende kerkorganisasies tot stand gekom het, dit net so min die eenheid van die kerk hoef te skaad as verskillende kerkverbande vanweë verskillende volke. Dit kan selfs goed wees dat daar verskillende kerkver- 
bande van dieselfde belydenis binne dieselfde volk bestaan om mekaar wakker te hou. In geval daar haat en nyd bestaan, is dit verkeerd en sleg, maar dan moet hierdie verkeerde nie deur een kerkverband nie maar deur samewerking in die liefde gesoek word. Die vraag kan aan die Ned Geref Kerk gestel word of sekondêre motiewe, soos die sending en ' $n$ eenheidsfront in optrede in die Afrikaanse volkslewe, nie vir hulle swaarder weeg as die fundamentele aspek van die eenheid in die waarheid nie (Notule TKK 1970: 117).

Met die Gereformeerde Kerke het daar diepgaande verskille oor hierdie saak aan die lig gekom. Hoewel die Gereformeerde Kerke ook die eenheid van die kerk as eenheid in die waarheid, in leer en belydenis aanvaar, stel die Kerk tog "dat as die "onsigbare" kerk één is in die waarheid, dan moet daardie eenheid sigbaar tot openbaring kom in die eenheid van kerkverband' (Notule TKK 1970: 117). Die natuurlike verskeidenheid tussen verskillende volke kan wel deur verskillende gemeentes verdiskonteer word, maar die eenheid moet deur een kerkverband sigbaar word. Dan spreek dit vanself dat binne een volk slegs een kerkverband mag bestaan. By die Gereformeerde Kerke word die eenheid in kerkorde klaarblyklik ook as konstitutiewe element vir die eenheid van die kerk ingeskuif. Hieragter 'lê natuurlik 'n hele kompleks van dogmatiese probleme wat sentreer rondom die begrippe onsigbare-sigbare kerk; ecclesia universalis - ecclesia localis; kerk as instituut - kerk as organisme' (Notule TKK 1970: 118).

In ' $n$ volgende memorandum is gehandel 'Oor die vraag of (die) drie (susters-) kerke met een en dieselfde belydenis binne een en dieselfde volk (met dieselfde taal, geskiedenis en kultuur) mag bestaan in die lig van die Bybels-reformatoriese visie oor die eenheid van die kerk van Jesus Christus' (Notule TKK 1972: 123 en Engelbrecht 1978: 285-289). Namens die Hervormde Kerk stel prof B J Engelbrecht dat die Bybel baie duidelik leer dat daar net een kerk van Jesus Christus kan wees. Die Reformatore het egter hierdie eenheid op 'n bepaalde manier op grond van die Skrif verstaan. Teenoor Rome wat die eenheid van die kerk stel in die sigbare eenheid van plek, organisasie en amp lê die eenheid van die kerk vir die Protestantisme in die eenheid van die waarheid, dit wil sê in die suiwere leer, belydenis, prediking, sakramentsbediening en Christelike lewe. Daarom kan die ware kerk oral teenwoordig wees, selfs in die Roomse Kerk. Die Lutherse en Calvinistiese kerke hoef daarom ook nie organisatories (institutêr) of amptelik (wat die amp betref) te verenig nie. Omdat hulle wat die capita doctrinae qua ecclesia Christi fundatur betref, ooreenstem, kan die 
feit dat hulle twee sigbare organisasies was, nie verhinder dat hulle één kerk van Jesus Christus is nie. Dat daar controversa ecclesia tussen hulle bestaan het, het ook nie noodwendig die eenheid van die kerk bedreig nie. Oor die contraversa ecclesia moet hulle met mekaar praat sodat die eenheid aan die lig kan tree, maar dan goed verstaan die eenheid in waarheid en nie in organisasie nie. Uit die voorgaande word gekonkludeer dat die blote bestaan van drie afsonderlike kerkorganisasies met dieselfde belydenis binne die een Afrikanervolksverband nie noodwendig die 'eenheid van die bruid van Christus' hoef te skaad nie. Reformatories gesien is hierdie drie kerke éên. Net so min as die bestaan van verskillende kerke onder die verskillende volke die eenheid van die kerk skaad, net so min hoef die bestaan van die drie Afrikaanse kerke die eenheid van die kerke van Jesus Christus onder die Afrikaner te skaad (Engelbrecht 1978: 288 en Notule TKK 1972: 127).

\section{SLOTOPMERKINGS}

Om nou terug te keer tot die vraag en ' $n$ antwoord te probeer gee of kerkvereniging vandag of in die toekoms 'n doelwit moet wees, kan die volgende opmerkings uit voorgaande gemaak word:

Die geskiedenis van ' $n$ honderd jaar gelede het ons geleer dat kerkvereniging op grond van ' $n$ nasionaal-politieke motief van volkseenheid ' $n$ bedenklike saak is wat groter twis, stryd en bitterheid tot gevolg kan hê as wat tevore tussen die afsonderlike kerke bestaan het. Hierdie motief tot organisatoriese eenwording van die drie kerke is steeds by baie eerder die primêre as sekondẻre oorweging, selfs al word dit self nie so raakgesien nie. As die kerke moet verenig omdat land en volk bedreig word of omdat die verskillende kerke dan die volkseenheid wegvreet (Notule TKK 1975: 195), kan 'n herhaling van die gebeure van die vorige eeu verwag word.

Vanuit die Bybels-Reformatoriese visie oor die eenheid van die kerk, soos die Hervormde Kerk dit verstaan, is die organisatoriese eenwording van die drie Afrikaanse kerke nie dwingende noodsaaklikheid om die eenheid van die kerk sigbaar te maak nie. Dit beteken natuurlik nie dat organisatoriese eenwording prinsipieel uitgesluit word nie. Tog sou dit nie verantwoord wees om iets wat nie ' $n$ Bybelse eis is nie, op een of ander wyse te probeer afdwing of deurdruk. Die herhaalde uitspraak van sondige verskeurdheid wat baie dikwels as niks anders as ' $n$ kwetsende beskuldiging 
teen die Hervormde Kerk bedoel is nie, sal in elk geval nooit 'n organisatoriese eenheid kan afdwing nie.

Niemand kan ontken dat daar ernstige en diepgaande verskille tussen die drie Afrikaanse kerke bestaan nie, selfs al het hulle dieselfde belydenis en vertak hulle uit dieselfde kerkhervorming. Dit het immers juis aan die lig gekom in die gesprekke in die TKK. Kerkbegrip, Skrifbeskouing, Skrifhantering en nog meer kan hier genoem word. Vir baie jare word hierdie verskille al met mekaar bespreek. Deur met mekaar hierdie verskille deur te praat, kan die eenheid des te meer aan die lig tree. Maar dan goed verstaan, die eenheid wat na vore moet kom, is die ware BybelsReformatoriese eenheid in die waarheid en nie die eenheid in organisasie en amp nie.

Geen argument is tot dusver in die debat oor kerkvereniging na vore gehaal wat dit vir die Hervormde Kerk nodig maak om sy bekende standpunt te wysig nie - 'n standpunt wat vanuit die Skrif, die Bybels-Reformatoriese teologie en die eie geskiedenis verantwoord kan word.

Daarom kan die volgende antwoord gegee word: Terwyl kerkvereniging nie prinsipieel afgewys word nie, is dit egter ook nie 'n prinsipiële eis dat daar slegs een sigbare kerklike organisasie of kerkverband onder die Afrikaner hoef te bestaan nie. Kerkvereniging kan wel 'n doelwit wees, maar hoef nie 'n doelwit te wees nie. Trouens vanuit die geskiedenis gesien en vanuit die huidige situasie en verhouding tussen die drie Afrikaanse kerke lyk kerkvereniging as doelwit vir die huidige en vir die toekoms, sover dit vooruit berekenbaar is, nie na 'n haalbare doelwit nie.

\section{Literatuurverwysings}

BOTHA, SJ 1981. Ds Marie Joseph Goddefroy 1848-1920: Sy lewe en betekenis. Pretoria: HAUM.

BOTHA, SJ 1985. Die kerkvereniging, in Die Almanak van die Nederduitsch Hervormde Kerk, Pretoria: NHW-Pers.

BOTHA, SJ [1961]. Ontleding van die kerksaak van Trichardtsfontein 1883. HTS 17/1.

BORCHARDT, CFA 1974. Die betrekkinge tussen die drie Afrikaanse kerke 1886-1973. NGTT 3/6.

DUVENHAGE, GDJ 1985. Die Eerste Vryheidsoorlog, in Die Almanak van die Nederduitsch Hervormde Kerk. Pretoria: NHW-Pers.

ENGELBRECHT, BJ 1978. Teologie in die Kerk. Pretoria: HAUM.

ENGELBRECHT, SP 1953. Geskiedenis oan die Nederduitsch Heroormde Kerk oan Afrika.

Kaapstad / Pretoria. 
GROBLER, HS 1983. Die Raad van die Nederduitse Gereformeerde Kerke. DD-proefskrif, Universiteit van Pretoria.

KRUGER, JC 1980. Kerkvereniging in die lig van uitverkiesing en bekering. Pretoria.

PONT, AD [1977]. Inleidende opmerkings oor 'sondige verskeurdheid'. HTS 33/3+4.

PONT, AD [1977]. Was die optrede van die Konsulentsgemeente 1886 'kerkskeurend'? HTS 33/3+4.

PONT, AD 1986. Verbond en volkskerk. HTS 42, 28-76.

STEENKAMP, JJ 1982. Unitas notae ecclesiae? in Die Kerk in die wêreld: 'n Bundel opstelle aangebied aan prof dr AD Pont by sy 25-jarige ampsjubileum, 171-182. Pretoria: HAUM.

NOTULE TUSSENKERKLIKE KOMMISSIE: Handelinge 1958-1981. 